\title{
Pilot-Scale Validation of a New Sensor for On-Line Analysis of Volatile Fatty Acids and Alkalinity in Anaerobic Wastewater Treatment Plants
}

\author{
Francisco Molina, ${ }^{1,2}$ Gonzalo Ruiz-Filippi, ${ }^{1,3}$ Carlos Garcia, ${ }^{1}$ Juan M. Lema, ${ }^{1}$ and Enrique Roca ${ }^{1, *}$ \\ ${ }^{1}$ Department of Chemical Engineering. School of Engineering, University of Santiago de Compostela, Spain \\ ${ }^{2}$ Department of Sanitary Engineering, University of Antioquia, Colombia \\ ${ }^{3}$ Biochemical Engineering School, Pontifical Catholic University of Valparaíso, Chile
}

Received: November 8, $2007 \quad$ Accepted in revised form: October 10, 2008

\begin{abstract}
This paper describes a validation procedure applied for an on-line titrimetric analyzer (AnaSense ${ }^{\circledR}$-Anaerobic Control Analyzer) prototype designed to detect of volatile fatty acids (VFA) and alkalinity (bicarbonate). The AnaSense $^{\circledR}$ analyzer was recently developed under the framework of the TELEMAC European Project. A pilot-scale evaluation of the analyzer was carried out in an anaerobic wastewater treatment plant, in a hybrid Upflow Sludge Bed Filter (USBF) reactor with an overall volume of $1.15 \mathrm{~m}^{3}$. The sensor uses two methods, both based on two-point titrimetric analyses, for determining VFA and alkalinity concentration. AnaSense ${ }^{\circledR}$ performed on-line monitoring of VFA (13-4,900 mg $\left.\cdot \mathrm{L}^{-1}\right)$ and bicarbonate $\left(2.5-49.5 \mathrm{mEq} \cdot \mathrm{L}^{-1}\right)$, and demonstrated sufficient accuracy for both VFA and bicarbonate detection. Intermediate Alkalinity/Total Alkalinity (IA/TA) and Intermediate Alkalinity/Partial Alkalinity (IA/PA) ratios were also evaluated to test the suitability of the sensor for anaerobic digestion process control.
\end{abstract}

Key words: anaerobic digestion, VFA, alkalinity, sensor validation, on-line instrumentation

\section{Introduction}

A N ANAEROBIC WASTEWATER TREATMENT (AWT) process is characterized by the complete conversion of organic pollutants in the wastewater into a mixture of gaseous products such as $\mathrm{CH}_{4}, \mathrm{CO}_{2}, \mathrm{H}_{2}$, and $\mathrm{H}_{2} \mathrm{~S}$ (Vanrolleghem and Lee, 2003). For wastewater containing mainly monomeric organic pollutants there are three steps in the conversion process: acidogenesis, acetogenesis, and methanogenesis (Henze and Harremoës, 1983). Organic matter is converted into organic volatile acids (mainly acetic, propionic, butyric, and valeric) during acidogenesis. In the acetogenesis step, volatile acids longer than two carbons are converted to acetic acid, $\mathrm{CO}_{2}$, and $\mathrm{H}_{2}$, which in turn, become $\mathrm{CH}_{4}$ through methanogenesis (Speece, 1996). These process steps must be well balanced to prevent volatile fatty acid (VFA) accumulation and thus to avoid a sudden drop in system $\mathrm{pH}$, which may lead to complete failure of the conversion process (Gujer and Zehnder, 1983; Switzembaum et al., 1990; Ahring et al., 1995; Tay and Zhang, 2000; Lahav et al., 2002a; Steyer et al., 2006).

*Corresponding author: University of Santiago de Compostela, Rua Lope Gómez de Marzoa, s/n, E-15782, Santiago de Compostela, Spain. Phone: +34 981563100-16774; Fax: + 34 981547168; E-mail: enrique.roca@usc.es
Successful operation of anaerobic process depends, among other operational parameters and conditions, on maintaining a system $\mathrm{pH}$ between 6.6 and 7.4 (Moosbrugger et al., 1992; Lahav et al., 2002b). Alkalinity depends on the relative concentrations of several compounds, such as carbonate/bicarbonate, phosphate, ammonia, and VFA, which impart buffer capacity. Bicarbonate and VFA are the main contributors to buffer capacity in the anaerobic digestion process (Hawkes et al., 1994).

McCarty (1964) proposed the use of alkalinity as a key parameter for anaerobic process control. A decrease in alkalinity is directly linked to an increase in VFA concentration. Because of this, Ripley et al. (1986) suggested the use of a partial and intermediate alkalinity ratio as a control parameter of the anaerobic digestion process. Titration from the original sample $\mathrm{pH}$ to a $\mathrm{pH}$ of 5.75 allows for the determination of partial alkalinity (PA), which corresponds roughly to the bicarbonate concentration (Jenkins et al., 1983). On the other hand, intermediate alkalinity (IA) can be obtained by a titration from a $\mathrm{pH}$ of 5.75 to a $\mathrm{pH}$ of 4.30 . IA corresponds to the contribution of VFA to total alkalinity (TA). Finally, TA can be calculated as the sum of PA and IA. Furthermore, the IA/TA or IA/PA ratios can be used, together with other indicators, as an effective control parameter (Ripley et al, 1986; Wentzel et al, 1994; Puñal et al., 2001).

Ripley et al. (1986) tested the suitability of the IA/PA ratio as a process stability index in bench-scale digesters fed 
with poultry manure. In this study, an IA/PA ratio of 0.3 was obtained as the optimal value for the successful digestion of poultry manure.

Other researchers (Puñal et al, 2001) found that a certain flexibility around the IA/TA ratio can be acceptable, especially when operating at a high buffering capacity in terms of total alkalinity (e.g., above $3 \mathrm{~g} \mathrm{CaCO}_{3} \cdot \mathrm{L}^{-1}$ ). In other words, the IA/TA value indicates, in relative terms, the degree to which buffering capacity corresponds to VFA concentration.

One successful approach for VFA and bicarbonate measurement may consist of a robust and low cost automatic titrimetric sensor suitable for industrial processes. Some researchers have proposed a two or three step titration analysis (Jenkins et al., 1983; Anderson and Yang, 1992; Kapp, 1992; Hawkes et al., 1994), while others have developed a more complex titration analysis. These procedures include four, five, or eight titration steps, which makes them less applicable at a full scale (Moosbrugger et al., 1992; Buchauer, 1998; Lahav and Loewenthal, 2000; Feitkenhauer et al., 2001; Bouvier et al., 2002; Lahav et al., 2002a; Lahav and Morgan, 2004). Based on these methods, on-line analyzers have been developed and used at lab scale in the last decade (Hawkes et al., 1994; Guwy et al., 1994; Bouvier et al., 2002; Vanrolleghem and Lee, 2003).
However, the application of these on-line sensors at the industrial scale was not successfully achieved due to their low robustness and poor performance.

A titrimetric sensor (AnaSense ${ }^{\circledR}$ ) was recently developed for on-line VFA and alkalinity monitoring within the framework of the TELEMAC European Project (Bernard et al., 2005). This sensor is currently commercially available (De Neve and Lievens, 2004); however, a validation procedure was required before it could be applied at the industrial level for bioprocess control purposes.

This paper describes the pilot-scale validation procedure of an AnaSense ${ }^{\circledR}$ on-line sensor prototype using two titrimetric methods. The validation was carried out using an anaerobic Upflow Sludge Bed Filter (USBF) operated under normal conditions and with organic overloads, so as to produce high VFA accumulation in the digester and a decrease in bicarbonate concentration. The aim was to assess the analyzer response over a wide range of organic loading rates (from low to high values of VFA and bicarbonate concentrations). The results of the validation were used to improve the analyzer and select the most appropriate measuring methodology. The IA/TA and IA/PA ratios were monitored to evaluate the sensor's suitability for automatic control of AWT plants under destabilization processes.

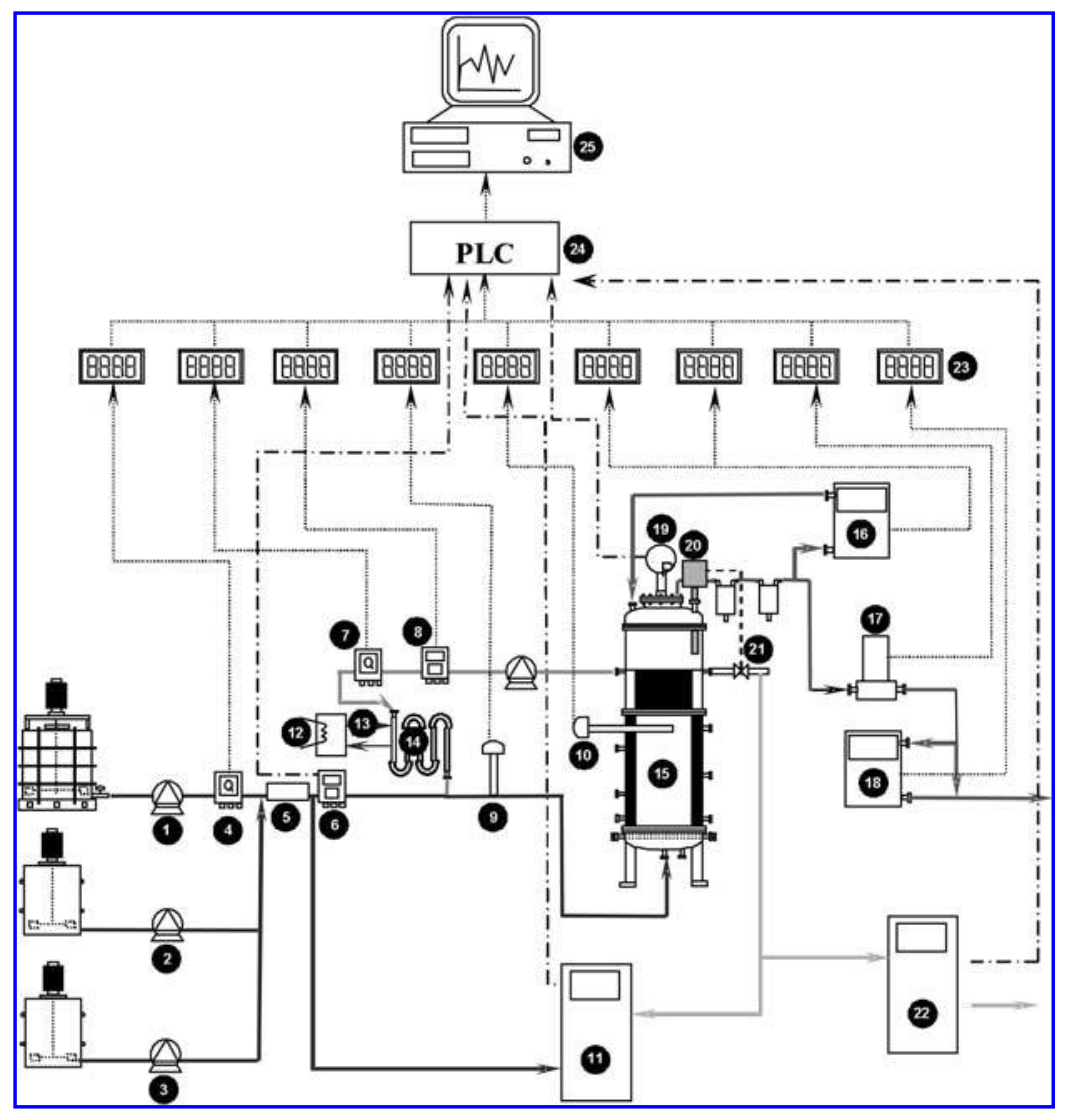

FIG. 1. Schematic layout of the pilot USBF: 1. Dilution pump; 2. nutrient pump; 3. wastewater pump; 4. dilution water flow meter; 5. static mixer; 6. Input $\mathrm{pH}$ meter; 7. recycling flow meter; 8 . output ph meter; 9 . input temperature probe; 10. reactor temperature probe; 11 . TOC on-line analyzer; 12 . water heater; 13 . Hot water pump; 14 . heat exchanger; 15. USBF reactor; 16. $\mathrm{CH}_{4}$ and $\mathrm{CO}$ analyzer; 17. gas flow meter; 18. hydrogen analyzer; 19. top pressure probe; 20 . Level sensor; 21. output valve; 22. alkalinity on-line sensor AnaSense ${ }^{\circledR} ; 2$. displays panel; 24. PLC; 25. PC; water and gas lines (continue line). Data flow (dotted line). 


\section{Materials and Methods}

\section{Pilot plant}

The pilot plant used for the validation experiments is based on a USBF. This hybrid digester has an overall volume of $1.15 \mathrm{~m}^{3}$, with a UASB (Upflow Anaerobic Sludge Blanket) of $0.85 \mathrm{~m}^{3}$ in the lower part and a UAF (Upflow Anaerobic Filter) of $0.3 \mathrm{~m}^{3}$ in the upper part. A high recycling flow rate $\left(200 \mathrm{~L} \cdot \mathrm{h}^{-1}\right)$ guarantees mixing. The hydrodynamics of the reactor can be well described by perfect mixing tanks in a series model. The behavior closely approximates a perfect mixing tank (1.2 tanks in series) according to a Residence Time Distribution experiment carried out using an $\mathrm{LiCl}$ aqueous solution as a tracer (Ruiz, 2005).

Dilute wine and dextrin solution were used as models of winery wastewater and rich carbohydrate wastewater, respectively. During validation experiments, the reactor was fed continuously with dilute wine plus nutrients (nitrogen and phosphorus) and alkalinity, until it reached a final COD/Bicarbonate/N/P ratio of 1,000/400/7/1 (Speece, 1996). This type of substrate was selected because of its high biodegradability since a fast response was desirable when carrying out organic overloads. Automatic control experiments (start-up and management of an organic overload) were carried out using a dextrin solution that had final COD/Bicarbonate/N/P ratio of $1,000 / 600 / 7 / 1$.

The on-line monitoring system of the pilot plant included feed and recycling electromagnetic flow meters (ABB, COPA-XE and Siemens, 7ME2531), input and output $\mathrm{pH}$ (Cole Palmer, Vernon Hills, IL) and temperature (Pt-100); a biogas flow meter (Brooks, 3240); an infrared gas analyser (Siemens, Ultramat 22P, New York) for measuring $\mathrm{CH}_{4}, \mathrm{CO}_{2}$, and $\mathrm{CO}$ concentrations in the gas line; a hydrogen gas analyser (Sensotrans, Sensotox 420) that utilized an electrochemical cell; total organic and inorganic carbon (TOC/TIC) was determined by catalyst oxidation and nondispersive infrared (NDIR) $\mathrm{CO}_{2}$ detection (Shimadzu, 4100). The signals from the sensors were recorded every $5 \mathrm{~s}$. Due to the high stability of the signal, the large time scale of the process, and hydraulic retention times between 10 and $20 \mathrm{~h}$, an average moving window of 15 min was selected for filtering these on-line signals. A more detailed description of the pilot plant and monitoring system has been given in previous papers (Fernandez et al., 2001; Ruiz et al., 2001). A flow-sheet of the pilot plant is shown in Fig. 1.

A microfiltration unit (Atech Innovations, MF $80 \mathrm{~nm}$ ) with a $0.8-\mu \mathrm{m}$ pore size was used to supply a suitable sample for TOC/TIC and AnaSense ${ }^{\circledR}$ analyzers. This filtration unit removed solids from the effluent, thereby avoiding pipe clogs and protecting the $\mathrm{pH}$ sensor. The microfiltration unit was operated at a maximum pressure of 1 bar and was cleaned every $48 \mathrm{~h}$. The filtration of effluent samples required approximately $15 \mathrm{~min}$ per sample. This more than acceptable considering the normal hydraulic retention times of anaerobic process are higher than the 10 to $15 \mathrm{~h}$ used in this work.

\section{AnaSense ${ }^{\circledR}$ analyzer}

The analyzer has two main parts (see Fig. 2). The upper part is a data processing unit with a PC (touch screen) and the lower part houses the analysis equipment compartment (titration vessel, micro burette, pumps, and chemical reser-

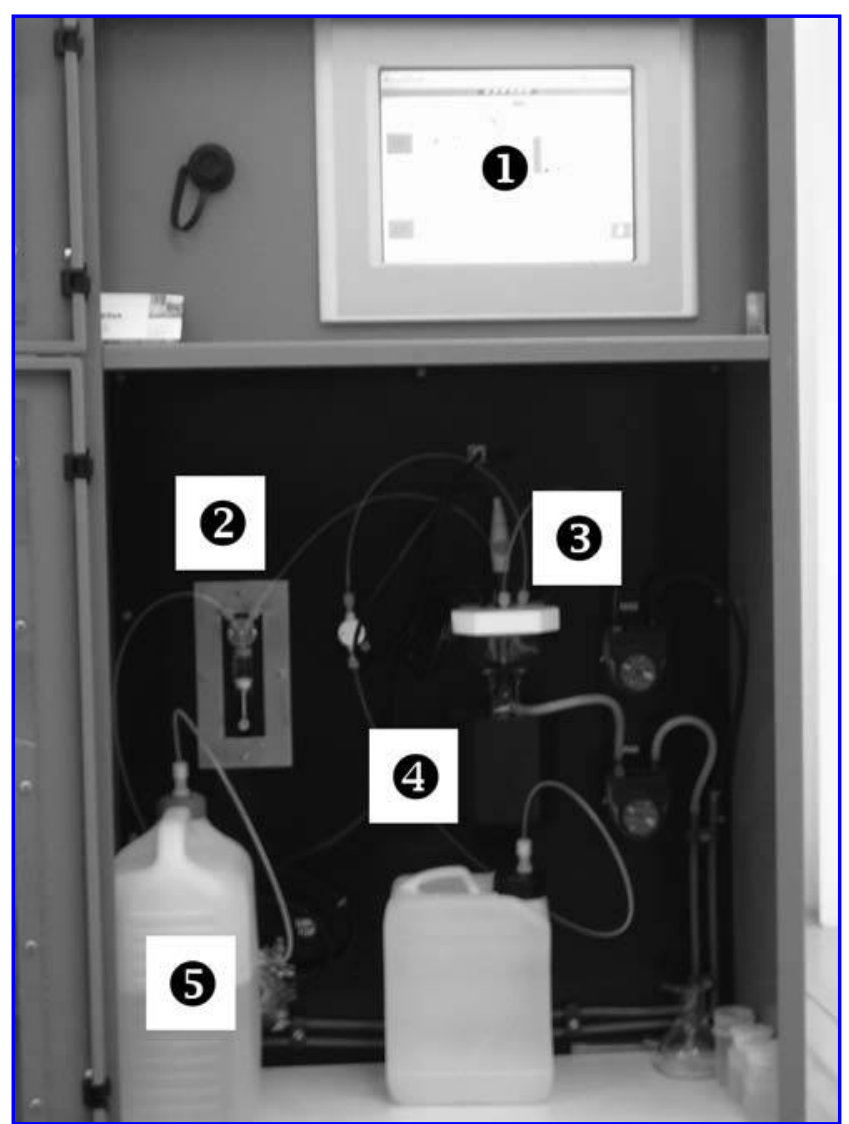

FIG. 2. Analyzer front view: 1. Display (touch); 2. microburette; 3. $\mathrm{pH}$ meter electrode; 4 . titration vessel; 5 . $\mathrm{HCl}$ $0.5 \mathrm{~N}$ reservoir.

voirs). The AnaSense ${ }^{\circledR}$ operative routine for each analysis begins with the injection of a sample volume of $10 \mathrm{ml}$ into the titration vessel. Subsequent dosing of the titrate solution $(\mathrm{HCl} 0.5 \mathrm{~N})$ is performed by a microburette with a minimum dosing step of $1 \mu \mathrm{L}$. VFA and bicarbonate (Bic) concentration estimates are carried out using recorded titration curves which allows for the calculation of PA, IA and TA. After each analysis, the vessel is drained by a pump so that a new sample can be analyzed. Carrying out the analysis requires 5 to 10 min, depending of the VFA concentration in the sample.

AnaSense ${ }^{\circledR}$ utilized two methods for VFA and bicarbonate determinations, which we called method 1 and method 2. Method 1 was developed at the INRA (Institut National de la Recherche Agronomique, France) by the Laboratory of Environmental Biotechnology (LBE-INRA) (Bouvier et al., 2002). It is based on Kapp's method for the detection of VFA and is extended for the measurement of bicarbonate (Kapp, 1992). The development of this method was based on a procedure suggested by McGhee (1968). According to McGhee, the amount of acid required to titrate a solution containing only VFA is proportional to the content or concentration of VFA. The only additional buffer considered in the calculation of Kapp's method is the carbonate subsystem $\mathrm{HCO}_{3}{ }^{-} / \mathrm{CO}_{2}$, which has a $\mathrm{pK}_{\mathrm{a}}$ of approximately 6.3 . The method is based on the assumption that the acid required to titrate a sample from $\mathrm{pH} 5.0$ to $\mathrm{pH} 4.0$ can be considered proportional to the VFAs concentration (Buchauer, 1998). 
Method 2 was developed by AppliTek (AppliTek NV, Belgium) and is also based on McGhee's method (1968). Method 2 was developed in order to provide an accurate and easy measurement of low VFA concentrations by air stripping the sample. It was noticed that bicarbonate and hydrogen sulphide can be stripped from the anaerobic samples (stripping of the VFA is not representative) at a $\mathrm{pH}$ higher than 5. Afterward, the VFA can be directly measured by a down-titration from $\mathrm{pH} 5$ to 4 (McGhee's method). This approach avoids the interference of bicarbonate in VFA determination.

During this experimental work, the routine of maintenance of the AnaSense ${ }^{\circledR}$ analyzer involved $\mathrm{pH}$ sensor calibration and twice weekly titration vessel cleaning.

\section{Analytical methods}

Reference values of VFA and bicarbonate concentrations were determined by an on-line total organic and inorganic carbon (TOC and TIC) automatic analyzer (Shimadzu TOC-5000, with NDIR detector and sample combustion). Filtered samples (effluent of micro filtration unit previously described) were analyzed for the determination of dissolved inorganic and organic carbon (DIC and DOC, respectively). Bicarbonate concentration was directly computed from the DIC concentration on the assumption that the entire dissolved inorganic carbon corresponds to bicarbonate.

VFA concentrations were estimated from the DOC values on the assumption that the entire DOC corresponds to VFA (acetic, propionic and butyric acids). This assumption was confirmed by the off-line determination of VFA by gas chromatography approximately every $50 \mathrm{~h}$. In each control interval, the VFA concentrations estimated from DOC were compared with values of three to five samples that were analyzed by chromatography. The titrimetric methods used by AnaSense ${ }^{\circledR}$ give the concentration of VFA expressed as equivalent acetic acid concentration.

\section{Validation experiments}

Open loop testing. A wide range of Organic Loading Rate (OLR; from normal to organic overload conditions) experiments were carried out in order to assess the analyzer response. With the aim of evaluating the analyzer behavior in a wide concentration range of both components, two different overloads were provoked in the reactor in order to generate an increase in VFA and a decrease in bicarbonate concentration.

The first overload consisted of a combined hydraulic and organic overload. A feed flow rate of $20 \mathrm{~L} \cdot \mathrm{h}^{-1}$ and a COD concentration of $8.25 \mathrm{~g} \cdot \mathrm{L}^{-1}$ (OLR of $3.8 \mathrm{~kg} \mathrm{COD} \cdot \mathrm{m}^{-3}$. day $^{-1}$ ) were used as initial conditions. During the first overload (0 to $200 \mathrm{~h}$ ), the feed flow rate and influent COD were increased to 100 and $360 \%$, respectively. According to this, the OLR increased up to a value of $25 \mathrm{~kg} \mathrm{COD} \cdot \mathrm{m}^{-3} \cdot$ day $^{-1}$. In the second overload (200 to $400 \mathrm{~h}$ ), an OLR of $8 \mathrm{~kg}$ COD $\cdot \mathrm{m}^{-3} \cdot$ day $^{-1}$ was obtained by increasing the influent COD concentration. Figure 3 shows this experimental evolution.

AnaSense ${ }^{\circledR}$ determined on-line VFA and bicarbonate concentrations each hour during the validation process. In parallel, the TOC analyzer determined DOC and DIC concentrations for the same period of time. Three to five samples were analyzed off-line by gas chromatography in order to check the VFA concentration approximately every $50 \mathrm{~h}$.

A linear fit of the data from overload experiment was done for each method against the reference values using Microsoft Excel $^{\circledR}$ statistical tools. Data regression was carried out for two concentration ranges: (1) The complete range of data (13 to $4900 \mathrm{mg} \cdot \mathrm{L}^{-1}$ for VFA and 2.5 to $49.5 \mathrm{meq} \cdot \mathrm{L}^{-1}$ for bicarbonate); and (2) the low concentration range (13 to 410 $\mathrm{mg} \cdot \mathrm{L}^{-1}$ of VFA and from 2.5 to $10 \mathrm{mEq} \cdot \mathrm{L}^{-1}$ of bicarbonate). In this last case, the aim was to prove whether the AnaSense ${ }^{\circledR}$ had sufficient sensitivity at low concentrations.

Automatic start-up and response to organic overload using the IA/TA ratio. We carried out an experiment that tests

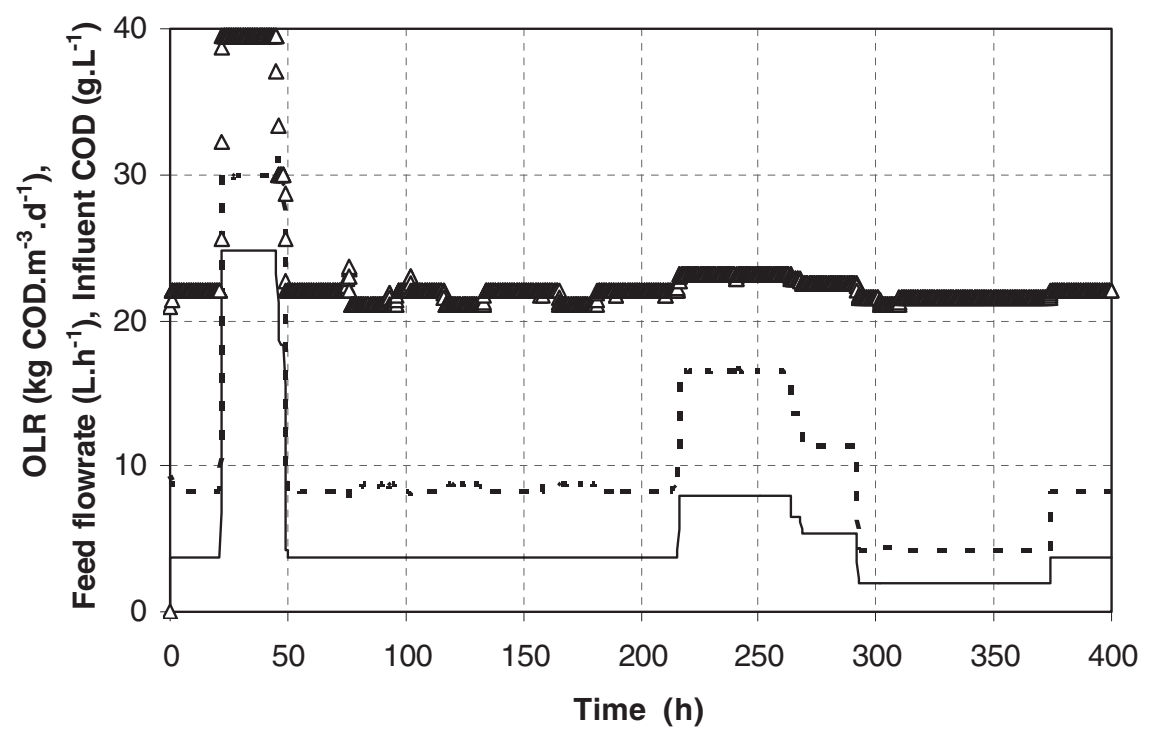

FIG. 3. Organic loading rate-OLR (-), feed flow-rate (- - -) and influent COD $(\Delta)$ applied during two organic overload experiments. 


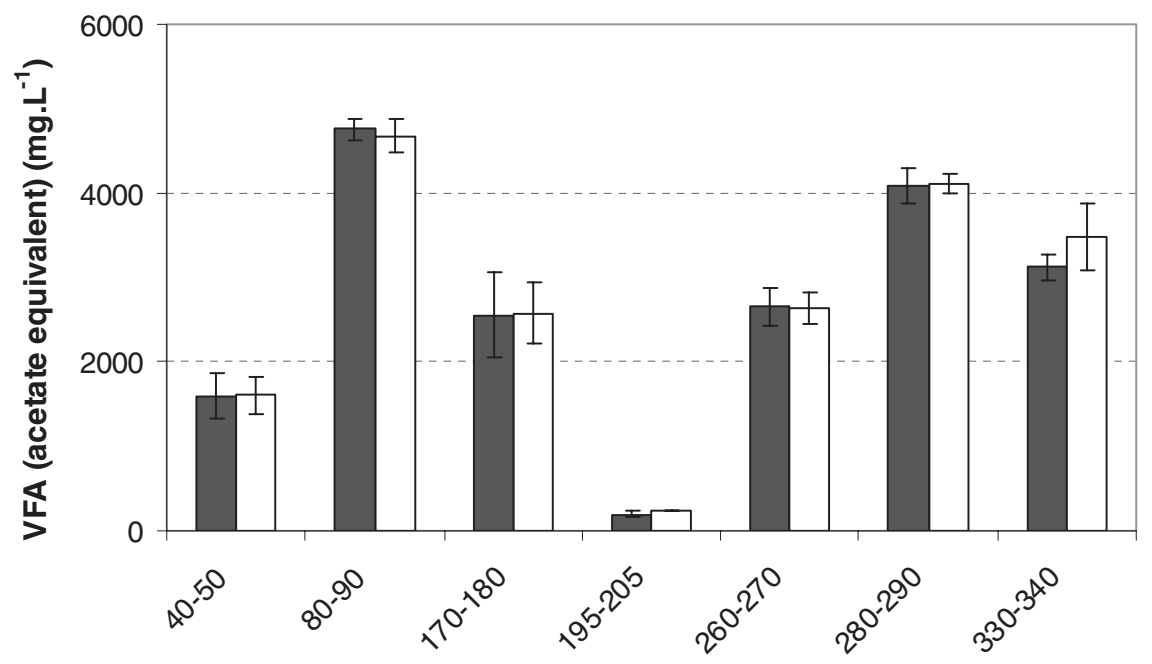

Time (h)

FIG. 4. Comparative values of VFA estimated by DOC concentration ( 四 ) versus VFA measured by chromatography ( $\mathrm{\text { }}$ ).

the suitability of the sensor for closed-loop control of the anaerobic process. This control system is based on fuzzy logic and was previously developed by Garcia et al. (2007). It involved the following process variables: IA/TA ratio, methane flow rate, and hydrogen concentration in gas phase. The controller sets up the feed flow rate using a knowledge base of 25 rules with a fuzzy inference based on Mamdani methodology (Mamdani and Assilian, 1975). The control system was implemented using the Matlab ${ }^{\circledR}$ Fuzzy Logic Toolbox.

The reliability of the AnaSense ${ }^{\circledR}$ in closed-loop control was tested during automatic start up and organic overload experiments. Normally, the recommended IA/TA ratio limit that assures the stability of the anaerobic treatment process is between 0.2 and 0.3 (Ripley et al., 1986). In the experiments, an IA/TA ratio value of 0.3 was used for the fuzzy controller. Input COD concentration was initially fixed to $3.15 \mathrm{~g} \cdot \mathrm{L}^{-1}$, and then, in a second step, an organic overload was applied by increasing COD concentration to $7 \mathrm{~g} \cdot \mathrm{L}^{-1}$.

\section{Results and Discussion}

All the conditions used to evaluate the system performance correspond to different scenarios that can be found at industrial level. The results obtained are presented here.

\section{Open loop testing during overloads experiments}

The instability of the anaerobic digestion process is usually related to the variation of wastewater quality and flow rate (Steyer et al., 2006). For this reason, the validation experiments were defined as organic and hydraulic overload scenarios.

AnaSense ${ }^{\circledR}$ was validated against VFA concentration values that were estimated from on-line DOC data. Therefore, it was necessary to provide a comparison with off-line Gas Chromatography determinations. This was performed throughout the validation process. Figure 4 shows a comparative analysis of average values and standard deviations of VFA concentrations estimated by DOC. It also shows VFA concentration measured by gas chromatography in all the measured ranges. It is clear that the results for both techniques were very similar, which indicates that the estimation of the VFA from on-line DOC analysis is adequate for this purpose.
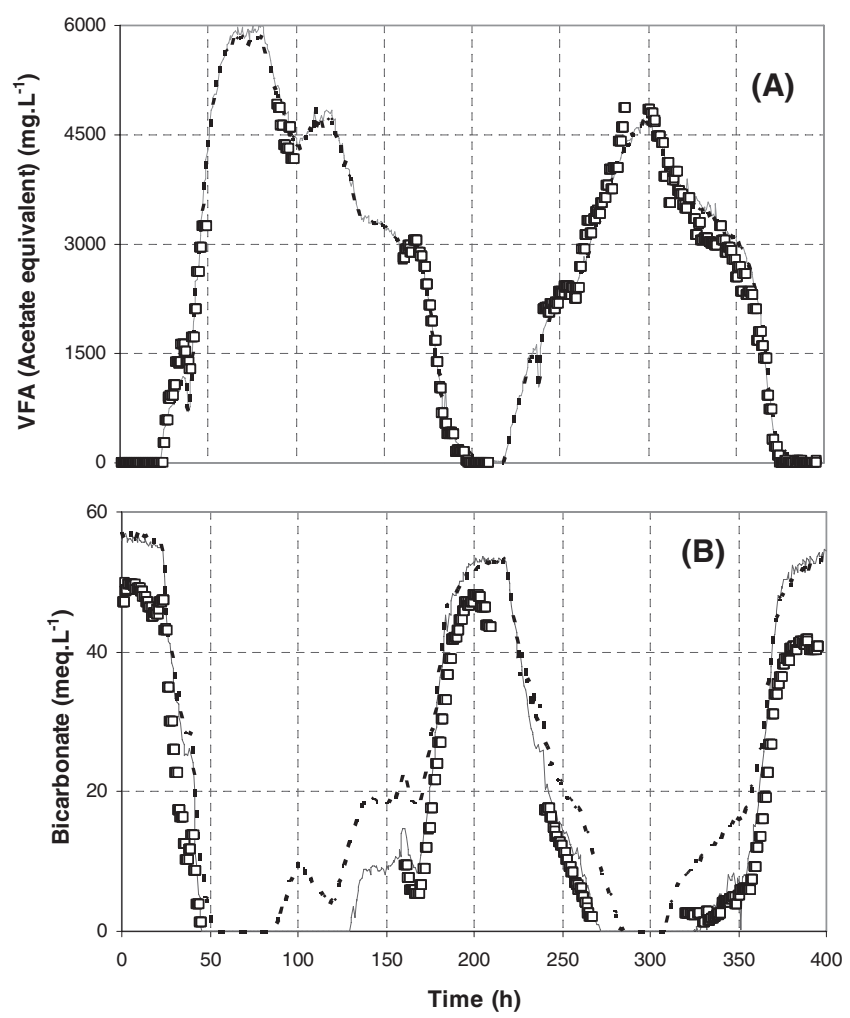

FIG. 5. (A) VFA reference values ( $\bigotimes)$ vs. estimate concentrations for method 1. (-) and method 2 (- - -) during two organic overload experiments. (B) Bicarbonate reference values $(\bigotimes)$ versus estimate concentration for method $1(-)$ and method 2 (- - ) during two organic overload experiments. 


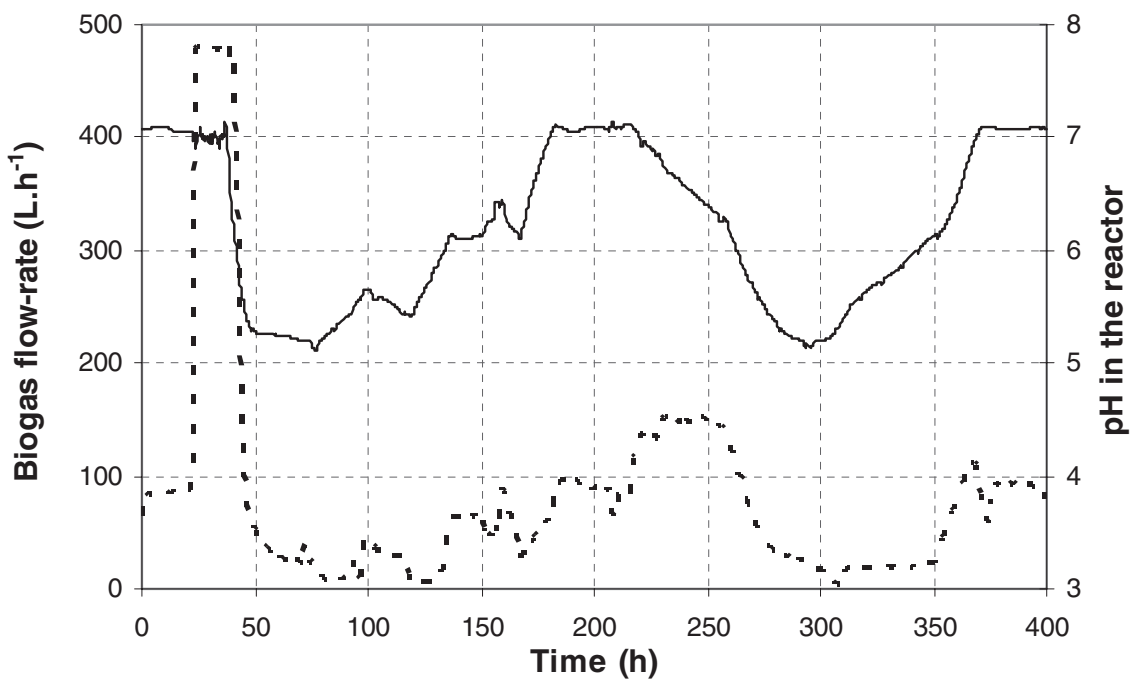

FIG. 6. Dynamic evolution of Biogas flow rate (- - ) and $\mathrm{pH}$ in the reactor (-) during two overloads experiments.

The VFA and bicarbonate estimates by methods 1 and 2 are presented in Fig. 5. The response of the process to both disturbances is shown in Fig. 6, which depicts the evolution of biogas flow rate and $\mathrm{pH}$ in the reactor. Both disturbances caused an initial increase in biogas flow-rate and a rapid rise of VFA concentration. At the same time, a decrease in bicarbonate concentration and $\mathrm{pH}$ was observed.

The first overload consisted of a combined hydraulic and organic overload that lasted $24 \mathrm{~h}$. The value of the OLR was $25 \mathrm{~kg} \mathrm{COD} \cdot \mathrm{m}^{-3} \cdot$ day $^{-1}$. As a result, the VFA concentration increased to $4,900 \mathrm{mg} \cdot \mathrm{L}^{-1}$ and the biogas flow rate sharply decreased, indicating a strong inhibition of the process. The $\mathrm{pH}$ value in the reactor dropped to 5.3, due to the lack of alkalinity, which favours an accumulation of VFA in its undissociated form. The microbial ecosystem was clearly overloaded at the end of the first overload. Subsequently, the process took approximately $150 \mathrm{~h}$ to recover. In the second overload (the organic overload), we applied for $40 \mathrm{~h}$ an OLR that was four times smaller than that used for the previous experiment $\left(8 \mathrm{~kg} \mathrm{COD} \cdot \mathrm{m}^{-3} \cdot \mathrm{day}^{-1}\right)$. However, the VFA concentration quickly increased to a value of $4,750 \mathrm{mg} \cdot \mathrm{L}^{-1}$ of equivalent acetic acid. This was due to the inhibition of the microbial ecosystem induced by the first overload. This behavior is typical in a reactor that has suffered a severe overload (Mathiot et al., 1992; Cord-Ruwisch et al., 1997; Vanrolleghem and Lee, 2003).

It can be seen in Fig. 5A that the results for VFA determination, which were obtained with AnaSense ${ }^{\circledR}$ using both methods, agree quite well with the corresponding reference data of concentrations of VFA, even at the lowest and the highest VFA values. Meanwhile, the estimate of bicarbonate presents a less appropriate response (see Fig. 5B). The estimated bicarbonate concentrations are greater than the reference values. Method 2 gave worse results. However, the estimated values from both methods agree with the tendency of bicarbonate concentration in the process.

It is important to note that the equipment showed a robust behavior since the response for VFA (both methods) and bicarbonate (method 1) was sufficiently accurate over the long period of the whole validation process. For example,
Fig. 7 shows the linear fit for the complete range of VFA concentrations.

Table 1 presents a summary of the linear fit parameters (intercept, slope, correlation coefficient and number of data) for both the complete range and the diluted concentrations range.

It is clear that for the VFA determination over the complete range of data, both methods performed well. They had a correlation coefficient $\left(R^{2}\right)$ of 0.98 and slopes close to one. For the low VFA concentration values (13-410 mg • $\left.\mathrm{L}^{-1}\right)$, method 1 gives the better fit $\left(R^{2}=0.87\right)$ with a slope near unity (1.12). Method 2 shows poorer results than method 1 with a correlation coefficient of 0.80 and slope of 1.16. Apparently (under the present experimental con-

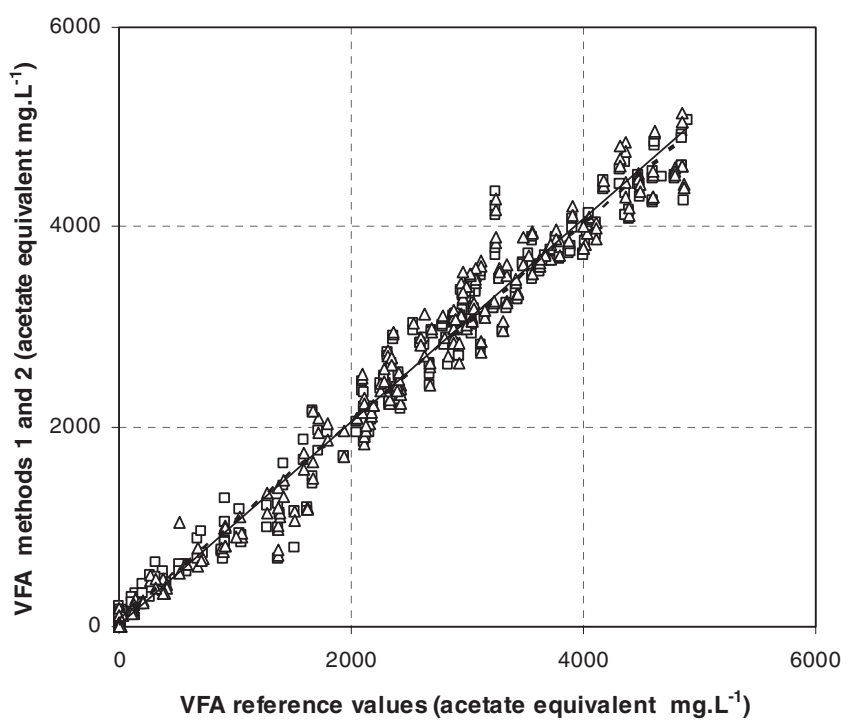

FIG. 7. VFA concentrations estimated by method $1(\Delta)$ and method $2(\bigotimes)$ vs. reference values. Linear fit of VFA by method 1 (-) and linear fit for VFA by Method 2(- - -). Complete range of data (13 to $4900 \mathrm{mg} \cdot \mathrm{L}^{-1}$ for VFA). 
Table 1. Summary of the Linear Fit Parameters for the Organic Overloads (Complete Range and Dilute Range)

VFA whole range $\left(13-4,900 \mathrm{mg} \cdot \mathrm{L}^{-1}\right.$ as acetic acid)

\begin{tabular}{lcccc}
\hline Method & $R^{2}$ & Slope & Intercept & $\begin{array}{c}\text { Number } \\
\text { of data }\end{array}$ \\
\hline 1 & 0.98 & 1.01 & 15 & 401 \\
2 & 0.98 & 0.99 & 41 & 407 \\
\hline
\end{tabular}

$V F A$ diluted range $\left(13-410 \mathrm{mg} \cdot \mathrm{L}^{-1}\right.$ as acetic acid)

\begin{tabular}{lcccc}
\hline Method & $R^{2}$ & Slope & Intercept & $\begin{array}{c}\text { Number } \\
\text { of data }\end{array}$ \\
\hline 1 & 0.87 & 1.12 & 25 & 24 \\
2 & 0.80 & 1.16 & 51 & 27 \\
\hline
\end{tabular}

Bicarbonate whole range $\left(2.5-49.5 \mathrm{meq} \cdot L^{-1}\right)$

\begin{tabular}{lcccc}
\hline Method & $R^{2}$ & Slope & Intercept & $\begin{array}{c}\text { Number } \\
\text { of data }\end{array}$ \\
\hline 1 & 0.98 & 1.15 & 2 & 410 \\
2 & 0.98 & 0.94 & 11 & 419 \\
\hline
\end{tabular}

Bicarbonate diluted range $\left(2.5-10 \mathrm{meq} \cdot \mathrm{L}^{-1}\right)$

\begin{tabular}{ccccc}
\hline Method & $R^{2}$ & Slope & Intercept & $\begin{array}{c}\text { Number } \\
\text { of data }\end{array}$ \\
\hline 1 & 0.78 & 1.50 & 0 & 37 \\
2 & 0.71 & 1.41 & 8 & 40
\end{tabular}

ditions), method 2 has no advantage over method 1 in the estimation of low VFA concentrations, despite air stripping the sample in order to remove bicarbonate and hydrogen sulphide.
For bicarbonate determination over the complete range, both methods showed a good correlation coefficient $\left(R^{2}=\right.$ 0.98 ) and slopes near unity. Moreover, method 2 gave the better slope (0.94). For the low bicarbonate concentration range $\left(2.5-10 \mathrm{mEq} \cdot \mathrm{L}^{-1}\right)$, both methods gave poor results, with correlation coefficients of 0.78 for method 1 and 0.71 for method 2; both methods had similar slopes (1.5 and 1.4, respectively).

\section{On-line monitoring of IA/TA and IA/PA ratios as process stability index}

It is well established that the efficient and stable operation of anaerobic digestion depends on having an adequate buffering capacity and nonexcessive VFA concentrations in the digester. Consequently, IA/TA and IA/PA ratios could be used as process stability indexes. However, the use of these indexes in practice requires the availability of reliable on-line sensors that have been shown to be applicable at industrial scale.

In the present work, PA, IA, and TA values were monitored on-line by AnaSense ${ }^{\circledR}$ using method 1, which gave better results in previous validation experiments. Figure 8 shows the effluent acetate equivalent concentration against the evolution of the IA/TA and IA/PA ratios. It is clear that both IA/TA and IA/PA ratios can be efficiently used and had similar performance. However, IA/PA presented a higher sensitivity than IA/TA, since the highest value of PA is equal to TA. According to these results, the safe operation of the anaerobic digester (without accumulation of VFA) could be obtained by maintaining IA/TA and IA/PA ratios lower than 0.2 and 0.25 , respectively. Both values agree with the threshold of 0.3 established by Ripley et al. (1986).

\section{Automatic start-up and response to organic overload using the IA/TA ratio}

Finally, a closed-loop control experiment was carried out using the IA/TA ratio as a stability index. The results ob-

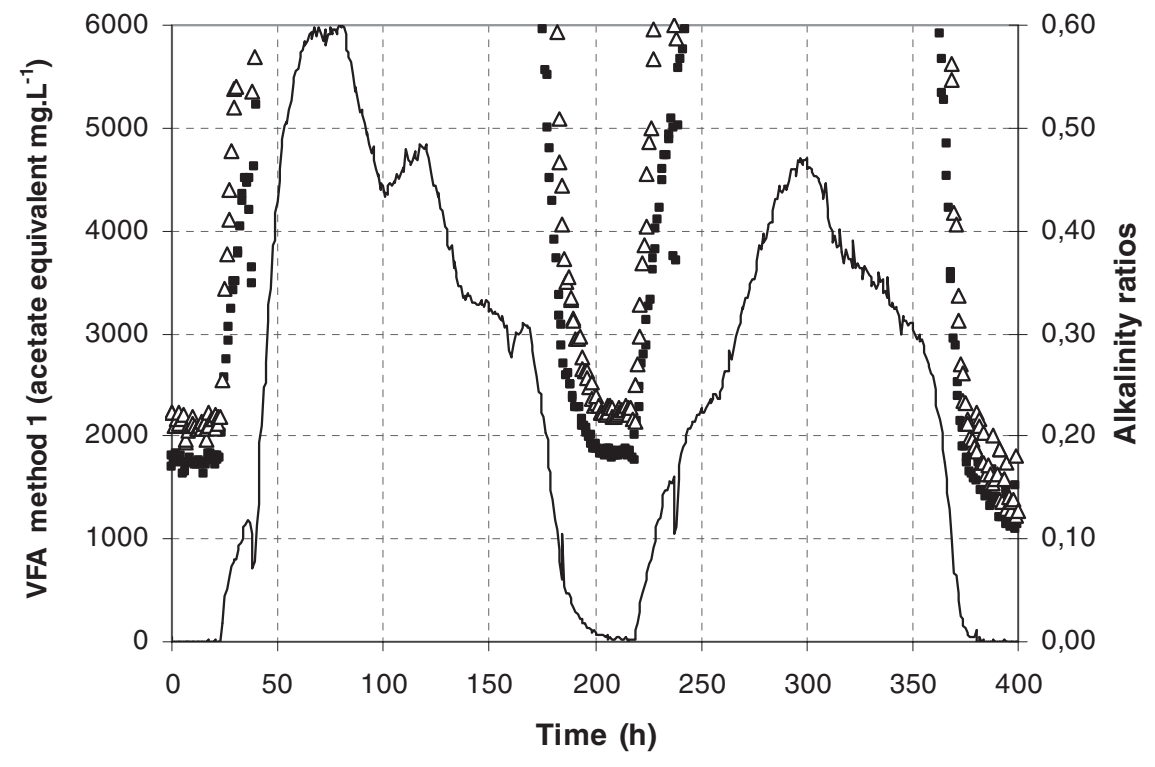

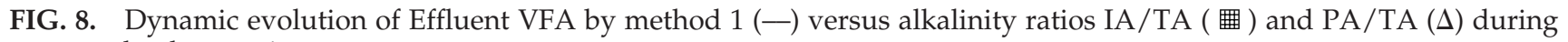
two overloads experiments. 

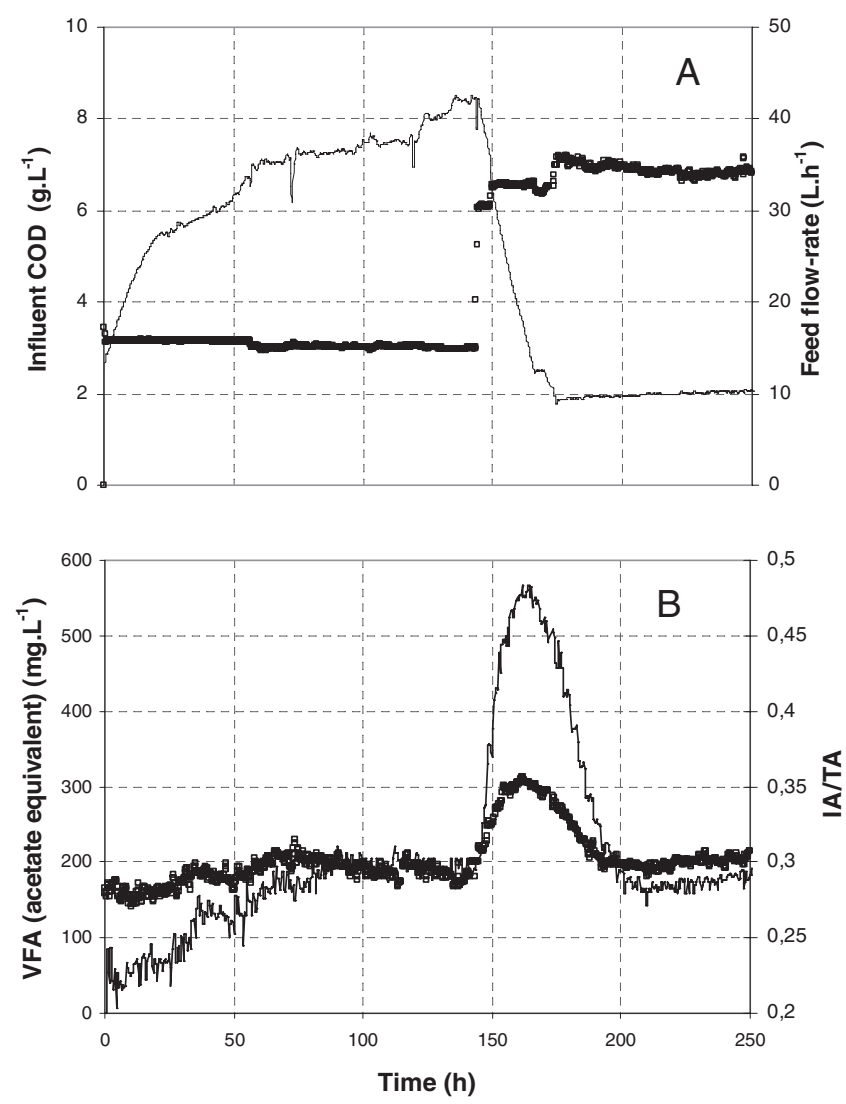

FIG. 9. (A) Feed flow-rate (-) and influent COD ( $\bigotimes)$ applied during the closed-loop experiment (start up and organic overload). (B) VFA concentrations (-) and IA/TA ratio $(\bigotimes)$ during the closed-loop experiment.

tained are shown in Fig. 9. The evolution of the feed flow rate and the change in the input COD concentration can be seen in Fig. 9A. Figure 9B presents the dynamics of the IA/TA ratio and VFA concentration during start-up and organic overload.

During the start-up process, the control system increases the feed flow rate while the anaerobic process is stable (values of the IA/TA ratio are below 0.3 and there is no accumulation of VFA). The system reached the operation capacity at a feed flow rate of $40 \mathrm{~L} \cdot \mathrm{h}^{-1}$ without accumulation of VFA (values were below $200 \mathrm{mg} \cdot \mathrm{L}^{-1}$ in the effluent). Afterward, an organic overload was applied by increasing the input COD concentration to $7 \mathrm{~g} \cdot \mathrm{L}^{-1}$ (on approximately the 145 th $\mathrm{h}$ of experimentation).

As a result of the overload, the IA/TA ratio reached values higher than the set point of 0.3 , and thus, the control system managed a decrease in the feed flow rate until the IA/TA ratio again recovered acceptable values (lower than the limit of 0.3 ). Finally, the feed flow rate was stabilized at $10 \mathrm{~L} / \mathrm{h}$ and the effluent VFA concentration returned to values close to $200 \mathrm{mg} \cdot \mathrm{L}^{-1}$.

\section{Sumary and Conclusions}

The AnaSense ${ }^{\circledR}$ titrimetric sensor was validated at the pilot scale in continuous operation. Each analysis of Anasense needs between 5 and 10 min to be carried out, depending of the VFA concentration in the sample. This time period can be modified for hydraulic retention times higher than $10 \mathrm{~h}$, which is useful for control purposes in AWT.

The main problem with the analyzer is the presence of solids in the sample. The use of a microfiltration unit for the sampling system allowed for clogging or fouling drawbacks to be avoided and ensured the proper functioning of the analyzer. The maintenance requirements only involved calibrating the $\mathrm{pH}$ probe and cleaning the titration vessel twice weekly.

Both methods exhibited good performances in the determination of the VFA and bicarbonate concentrations for the complete range of concentrations $\left(13-4,900 \mathrm{mg} \cdot \mathrm{L}^{-1}\right.$ and 2.5-49.5 $\mathrm{mEq} \cdot \mathrm{L}^{-1}$ respectively).

For low range of VFA and bicarbonate concentrations, both methods displayed worse results; nevertheless, the results allowed the evolution of the process to be followed. Over the range of experimental conditions, method 1 presented a high efficiency and reliability.

AnaSense ${ }^{\circledR}$ showed a good performance for determining on-line alkalinity ratio (IA/TA and IA/PA), which are well established as stability indexes for anaerobic processes and provide useful information as control parameters. Thus, this equipment is suitable for being used to monitor the alkalinity ratio for the purposes of closed-loop control in wastewater treated by anaerobic digestion processes. AnaSense ${ }^{\circledR}$ is also a good option for the industrial implementation of other previously developed controllers (Bernard et al., 2001; Puñal et al., 2003) and advanced diagnosis systems (Tay and Zhang, 2000; Puñal et al., 2002) that are based on VFA concentrations and/or IA/TA ratios.

\section{Acknowledgments}

This work was carried out with the support provided by the European commission, Information Society Technologies Program, Key action I Systems \& Services for the Citizen, contract TELEMAC number IST-2000-28256; the National Spanish R\&D and the European Regional Development Fund (ERDF) through the project ANACOM CTQ200407811-C02-01; and Xunta de Galicia through the project SEDDAN (PGIDIT04TAM265006PR). The authors also acknowledge Applitek for the supply of and technical assistance with AnaSense $^{\circledR}$.

\section{Author Disclosure Statement}

The authors declare that no competing financial interests exist.

\section{References}

Ahring, B.K., Sanderberg, M., and Angelidaki, I. (1995). Volatile fatty acids as indicators of process imbalance in anaerobic digestors. Appl. Microb. Biotechnol. 43, 559.

Anderson, G.K., and Yang, G. (1992). Determination of bicarbonate and total volatile acid concentration in anaerobic digesters using a simple titration. Water Environ. Res. 64, 53.

Bernard, O., Polit, M., Hadj-Sadok, Z., Pengov, M., Dochain, D., Estaben, M., and Labat, P. (2001). Advanced monitoring and control of anaerobic wastewater treatment plants: Software 
sensors and controllers for an anaerobic digester. Water Sci. Technol. 43, 175.

Bernard, O., Chachuat, B., Helias, A., Le Dantec, B., Sialve, B., Steyer, J.-P., Lardon, L., Neveu, P., Lambert, S., Ratini, P., et al. (2005). TELEMAC: An integrated system to remote monitor and control anaerobic wastewater treatment plants through the internet. Water Sci. Technol. 52, 457.

Bouvier, J., Steyer, J.P., and Delgenes, J.P. (2002). On-line titrimettric sensor for the control of VFA and/or alkalinity in anaerobic digestion processes treating industrial vinasses. In: A.Noyola and O. Monroy, Eds., Proceedings VII Latin American Workshop and Symposium on Anaerobic Digestion, Merida, Mexico, pp. 65-68.

Buchauer, K. (1998). A comparison of two simple titration procedures to determine volatile fatty acids in influents to wastewater and sludge treatment processes. Water SA. 24, 49.

Cord-Ruwisch, R., Mercz, T.I., Hoh, C.Y., and Strong, G.E. (1997). Dissolved hydrogen concentration as an on-line control parameter for the automated operation and optimization of anaerobic digesters. Biotechnol. Bioeng., 56, 627.

De Neve, K., and Lievens, K. (2004). On-line analyser solves monitoring problem in bio-digester. Water Wastewater Int. 19, 28.

Feitkenhauer, H., Von Sachs, J., and Meyer, U. (2001). On-line titration of volatile fatty acids for the process control of anaerobic digestion plants. Water Res. 36, 212.

Fernandez, J.M., Omil, F., Mendez, R., and Lema, J.M. (2001). Anaerobic treatment of fibreboard manufacturing wastewaters in a pilot scale hybrid USBF reactor. Water Res. 35, 4150.

Garcia, C., Molina, F., Roca, E., and Lema, J.M. (2007). Fuzzybased control of an anaerobic reactor treating wastewaters containing ethanol and carbohydrates. Ind. Eng. Chem. Res. 46, 6707.

Gujer, W., and Zehnder, J.B. (1983). Conversion processes in anaerobic digestion. Water Sci. Technol. 15, 127

Guwy, A.J., Hawkes, D.L., Hawkes, F.R., and Rozzi, A.G. (1994). Characterization of a prototype industrial on-line analizer for bicarbonate/carbonate monitoring. Biotechnol. Bioeng. 44, 1325.

Hawkes, F.R., Guwy, A.J., Hawkes, D.L., and Rozzi, A.G. (1994). On-line monitoring of anaerobic digestion: Application of a device for continuous measurement of bicarbonate alkalinity. Water Sci. Technol. 30, 1.

Henze, M. and Harremoës, P. (1983). Anaerobic treatment of wastewater in fixed film reactors-A literature review. Water Sci. Technol. 15, 1.

Jenkins, S.R., Morgan, J.M., and Sawyer, C.L. (1983). Measuring anaerobic sludge digestion and growth by a simple alkalimetric titration. J WPCF 55, 448.

Kapp, H. (1992). On line messung der organischen saüren. Korrespondenz Abwasser. 39, 999.

Lahav, O., and Loewenthal, R.E. (2000). Measurement of VFA in anaerobic digestion: The five-point titration method revisited. Water SA. 26, 389.

Lahav, O., and Morgan, B.E. (2004). Titration methodologies for monitoring of anaerobic digestion in developing countries-a review. L. Chem. Technol. Biotechnol. 79, 1331.

Lahav, O., Morgan, B.E., and Loewenthal, R.E. (2002a). Rapid, simple and accurate method for measurement of VFA and carbonate alkalinity in anaerobic reactors. Environ. Sci. Technol. $36,2736$.

Lahav, O., Shlafman, E., Morgan, B.E., Loewenthal, R.E., and Tarre, S. (2002b). Accurate on-site volatile fatty acids (VFA) measurement in anaerobic digestion-verification of a new titrative method. In: A. Noyola and O. Monroy, Eds., Proceedings VII Latin American Workshop and Symposium on Anaerobic Digestion, Merida, Mexico,, pp. 118-125.

Lahav, O. and Morgan, B.E. (2004). Titration methodologies for monitoring of anaerobic digestion in developing countries-a review. L Chem. Technol. Biotechnol. 79, 1331.

Mamdani, E.H., and Assilian, S. (1975). An experiment in linguistic synthesis with a fuzzy logic controller. Int. J. Man-Machine Sudies. 7, 1.

Mathiot, S., Escoffier, Y., Ehlinger, F., Couderc, J.P., Leyris, J.P., and Moletta, R. (1992). Control parameter variations in an anaerobic fluidised bed reactor subjected to organic shockloads. Water Sci. Technol.. 25, 93.

Mccarty, P.L. (1964). Anaerobic waste treatment fundamentals. Part two. Environmental requirements and control. Public Works. 95, 123.

Mcghee, J. (1968). A method for approximation of volatile acid concentrations in anaerobic digesters. Water Sew. Works. 115, 162.

Moosbrugger, R.E., Wentzel, M.C., Ekama, G.A., and Marais, G.V. (1992). Simple titration procedures to determine $\mathrm{H}_{2} \mathrm{CO}_{3}{ }^{*}$ alkalinity and short-chain fatty acids in aqueous solutions containing known concentrations of ammonium, phosphate and sulphide weak acid/bases. WRC Report No TT 57/92. Pretoria, South Africa.

Puñal, A., Melloni, P., Roca, E., Rozzi, A., and Lema, JM. (2001). Automatic start-up of UASB reactors. IEnviron. Eng. 127, 397.

Puñal, A., Roca, E., and Lema, J.M. (2002). An expert system for monitoring and diagnosis of anaerobic wastewater treatment plants. Water Res. 36, 2656.

Puñal, A., Palazzotto, L., Bouvier, J.C., Conte, T., and Steyer, J. P. (2003). Automatic control of volatile fatty acids in anaerobic digestion using a fuzzy logic based approach. Water Sci. Technol. 48, 103.

Ripley, L., Boyle, W., and Converse, J. (1986). Improved alkalimetric monitoring for anaerobic digestion of high-strenght wastes. J WPCF 58, 406.

Ruiz, G. (2005). Advanced monitoring and control of anaerobic reactors. PhD Thesis. University of Santiago de Compostela (in Spanish).

Ruiz, G., Rodriguez, J., Baeza, J., Roca, E., and Lema, JM. (2001). Advanced monitoring and supervision of an anaerobic pilot plant. In: A.F. van Velsen and W. Verstraete, Eds., Proceedings of the Anaerobic Digestion World Congress (AD9), Technologisch Instituut vzw, Antwerpen, pp. 207-210.

Speece, R.E. (1996). Anaerobic Biotechnology for Industrial Wastewaters. Archae Press, USA.

Steyer, J.P., Bernard, O., Batstone, D.J., and Angelidaki, I. (2006). Lessons learnt from 15 years of ICA in anaerobic digesters. Water Sci. Technol.. 53, 25.

Switzembaum, M.S., Giraldo-Gómez, E., and Hickey R.F. (1990). Monitoring of the anaerobic methane fermentation process. Enzyme Microb. Technol. 12, 722.

Tay, J., and Zhang, X. (2000). Stability of high rate anaerobic systems. I: Performance under shocks. I. Environ. Eng. 126, 713.

Vanrolleghem, P.A., and Lee, D.S. (2003). On-line monitoring equipment for wastewater treatment processes: State of the art. Water Sci. Technol. 47, 1.

Wentzel, M.C., Moosbrugger, R.E., Sam-Soon, P.A.L.N.S., Ekama, G.A., and Marais, G.V.R. (1994). Tentative guidelines for waste selection, process design, operation and control of upflow anaerobic sludge bed reactors. Water Sci. Technol. 30, 31. 
